\title{
MENELUSURI ARGUMENTASI PENOLAKAN AL-SYAFI'IY TERHADAP ISTIHSAN SEBAGAI DALIL HUKUM
}

\author{
Nasruddin Yusuf ${ }^{1}$
}

\begin{abstract}
Abstrak
Adanya perbedaan dalam kehujjahan istihsân di kalangan ulama pada hakekatnya didasarkan kepada tidak sepakatnya pihak yang berselisih tentang cakupan dan pengertian istihsân, Ulama yang menggunakan istihsân sebagai hujjah menyampaikan kepada ulama yang tidak menggunakan istihsân sebagai hujjah dengan pengertian lain. Jika mereka yang berbeda pendapat itu sepakat mengenai batasan pengertian istihsân, maka sudah pasti mereka tidak akan berbeda pendapat tentang istihsân dapat dijadikan sebagai hujjah dan dalil hukum. Sebab pada dasarnya istihsân itu adalah pindahnya seorang mujahid dari dalil yang jelas atau dari hukum kulliy karena ada dalil yang menuntut perpindahan itu, sehingga tidak dapat dikategorikan pembentukan hukum dengan nafsu.
\end{abstract}

Kata Kunci: Sumber Hukum, Istihsan, Penetapan Hukum.

\section{A. Pendahuluan}

Di dalam ajaran Islam Al-Qur'an dan hadis merupakan sumber pokok pengambilan hukum Islam. Karena itu melalui petunjuk yang diambil dari keduanya masyarakat Islam mengamalkan seluruh petunjuk-petunjuk hukum yang dikandung. Al-Qur'an sebagai sumber pokok pertama merupakan wahyu Allah yang diturunkan kepada Nabi Muhammad saw (w. 632 M./11 H.) secara berangsur-angsur selama lebih dari dua puluh dua tahun dimulai di Makkah dan disudahi di Madinah. Sedangkan hadis sebagai sumber pokok kedua yang berisi perkataan, perbuatan, dan

\footnotetext{
${ }^{1}$ Penulis adalah dosen tetap pada Jurusan Syari'ah STAIN Manado.
} 
taqrîr ${ }^{2}$ Nabi berfungsi menjelaskan (bayân) bagi maksud-maksud Al-Qur'an yang masih umum dan terbatas. ${ }^{3}$

Selain kedua sumber pokok tadi, untuk memperoleh ketentuan hukum yang tidak disebutkan oleh keduanya disebabkan informasi yang terbatas dari Al-Qur'an dan hadis, maka menurut ulama pengambilan hukum dapat juga diperoleh dengan

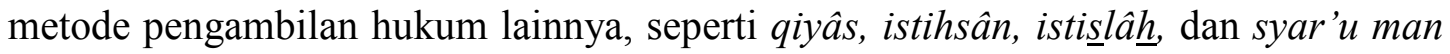
qablanâ, dan lain sebagainya. Keseluruhan metode itu boleh ditetapkan sebagai sumber hukum dengan tidak bertentangan dengan sumber pokok, Al-Qur'an dan hadis. Keseluruhan sumber pengambilan hukum, baik sumber utamanya maupun metode pengambilan hukum lainnya di dalam Ilmu Ushul Fikih ${ }^{4}$ disebut dengan aladillah al-syar'iyyah (dalil-dalil syarak). ${ }^{5}$

Namun dalam kenyataannya tidak semua sumber disepakati sebagai dalil hukum, hanya Al-Qur'an, hadis, ijmak dan qiyas saja yang banyak disepakati ulama. Selain sumber dan dalil tadi, para ulama masih memiliki perbedaan pandangan. Di dalam tulisan ini akan dibahas satu dalil hukum yang terkait dengan perbedaan pandangan tadi, khususnya berkaitan dengan argumentasi Imam al-Syafi'iy terhadap penolakannya menjadikan dalil istihsan sebagai salah satu dalil hukum yang merupakan dalil hukum yang serikali dipakai oleh Imam Abu Hanifah.

${ }^{2}$ Taqrîr adalah perbuatan sahabat Nabi yang diketahui dan tidak dikoreksi Nabi. Taqrîr yang demikian disebut dengan taqrîr sarihîy. Sedangkan perbuatan sahabat Nabi yang tidak disaksikan Nabi secara langsung saat terjadinya disebut dengan taqrîr hukmiy. Taqrîr hukmiy diperselisihkan

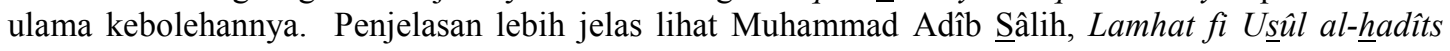
(Beirut: al-Maktab al-Islâmiy, 1399 H.); Muhammad ibn Ismaîl al-Sૂanânî, Taudîh $\underline{h}$ al-Afkâr li Ma 'âni Tanqîh al-Anzârr, Juz I (Kairo: Maktabah Khânijiy, 1966 M.), h. 276-278.

3. Mustafâ al-Sibâiy, al-Sunnah wa Makânatuhâ fì al-Tasyrî' al-Islâmiy (t.tp.: Dâr alQaumiyyah, 1966), hal. 53-54: Abû Ishaq Ibrahim ibn Musa al-Syâtibi, al-Muwafaqat fi Us ûl alSyarî'ah, Juz IV (Mesir: al-Maktabah al-Tujariyyah al-Kubra, t.t.) hal. 3-7; Fazlurrahman, Islam (Chicago: university of Chicago Press, 1979), hal. 53-58; Syed Mahmudunnasir, Islamic Concept and History (New Delhi: Nusrat Ali Nasri for Kitab Bhavan, 1981), h. 108-115.

${ }^{4}$ Ilmu Ushul Fikih adalah ilmu yang menjelaskan metode-metode yang digunakan para mujtahid untuk keperluan istinbât hukum-hukum agama dari nas-nas dengan mengeluarkan 'illah'illah yang ditegakkan hukum di atasnya dan menyentuh maslahat-maslahat yang dikehendaki oleh Syarak, baik melalui isyarat Alquran maupun petunjuk-petunjuk dan penjelasan-penjelasan hadis. Lihat Muhammad Abû Zahrah, Ushûl al-Fiqh (T.tp.: Dâr al-Fikr al-'Arabîy, t. t), h. 3.

${ }^{5}$ Muhammad Mûsa Tiwâna, al-Ijtihâd (T.tp.: Dâr al-Kutub al-Hadîtsah, t.t. ), h. 368. 


\section{B. Pengertian Dan Ruang Lingkup Istihsan}

Secara bahasa seperti yang dipahami ulama, istiḩsân berarti menyatakan dan menyakini baiknya sesuatu. Ulama ushul sepakat dalam mengunakan makna tersebut dalam pengertian bahasa. ${ }^{6}$ Sedangkan pengertian istihsân secara terminologi diartikan dengan :

1. Al-Bazdâwiy (w. 482 H./1079 M.)

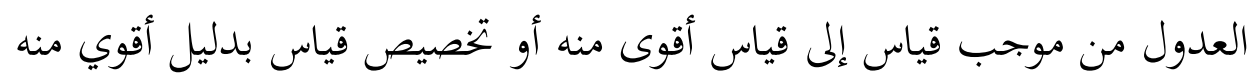

Berpalingnya seorang mujtahid dari suatu ketentuan qiyâs kepada qiyâs yang lebih kuat, ataupun mengkhususkan qiyâs dengan dalil yang lebih kuat. ${ }^{7}$

2. Al-Sarkhâsiy (w. 483 H./1090 M.)

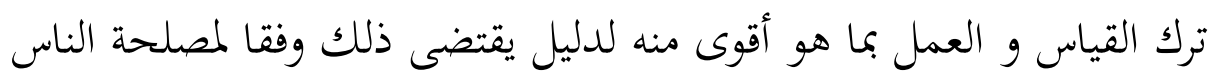

Istiḩsân berarti meninggalkan qiyâs dan mengamalkan yang lebih kuat dari itu, karena adanya dalil yang menghendaki demikian dan lebih sesuai bagi kemaslahatan manusia. ${ }^{8}$

3. 'Abd al-Wahâb Khallâf

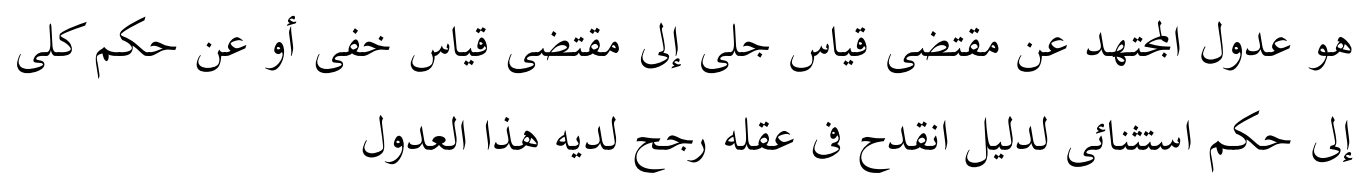

"Berpindahnya seorang mujtahid dari tuntutan qiyâs jaliy kepada qiyâs khafiy,

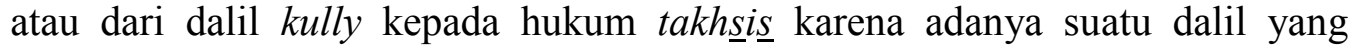
menyebabkan seorang mujtahid mesti menyalahkan cara berpikirnya dan mementingkan perpindahan"9

${ }^{6}$ Al-Sarkhasiy, Usul al-Sarakhasiy, jilid II (Beirut: Dar al-Kutub al-'Ilmiyyah, 1993) hal. 200; al-Amidiy, al-Ihkam, Jilid III, hal. 126.

${ }^{7}$ Ibid., h. 200.

${ }^{8}$ Al-Sarkhasiy, Usul, Jilid III, h. 200.

9 'Abd al-Wahâb Khallâf, 'Ilm Usîul..,, h. 79. 
Dalam kajian ilmu ushul fikih, metode istiḩsân dan istis lâh merupakan metode istinbât hukum yang sering diperselisihkan ulama status kekuatannya. Keduanya lazim disebut di dalam lingkungan dalil-dalil yang mukhtalaf fih. Istihssân dan istis $l \hat{a} \underline{h}$ keduanya banyak digunakan oleh madzhab Hanafi dan Maliki, tetapi ditolak madzhab Syafi'iy dan Hanbali. Al-Syâfi'iy sampai perlu menulis buku tersendiri dengan judul ibtal al-istiḩsân yang termuat di dalam kitab al-umm dalam membantah argumentasi istih hân tersebut.

Dalam salah satu riwayat dari Muhammad ibn Hasan al-Syaibaniy tentang penggunaan istihsan ini, diceritakan bahwa jika imam mereka, Abu Hanifah telah melakukan ijtihad dengan metode istiḩsân dalam masalah-masalah yang diperlukan qiyâs, maka tidak seorangpun dari lawan diskusinya yang dapat memberikan bandingan dan tanggapan lagi. Mereka pun menerima argumen yang dikemukakan Abu Hanifah dan seterusnya mengikuti pendapatnya berdasarkan dalil istihssân tersebut. Karena itu mereka senantiasa membiarkan dan menyerahkan penyelesaiannya secara penuh kepada Abu Hanifah. ${ }^{10}$ Langkah istinbât hukum melalui dalil istiḩsân yang dikenalkan oleh Imam Abu Hanifah itu kemudian banyak diikuti oleh muridnya Muhammad ibn Hasan al-Syaibaniy. Di dalam tulisantulisannya beliau banyak mengatakan astahsinu wa adâ al-qiyâs dalam kitab mabsutnya. Kata astahsinu wa ada al-qiyas memberikan arti bahwa dalil yang dipakai adalah dalil istihsan dengan tetap mempertimbangkan adanya dalil qiyas, suatu dalil hukum yang disepakati kehujjahannya oleh ulama.

Sesungguhnya terdapat relevansi yang dekat antara qiyas dan istihsan ditinjau dari segi dalil yang digunakan pada saat beralih dari qiyâs, Istiḩsân dapat dibagi kepada dua bentuk. Pertama, yaitu istihssân yang lebih mengutamakan penerapan qiyâs khafi dari qiyâs jaliy berdasarkan dalil. Penerapan seperti itu terjadi disebabkan qiyâs yang jaliy tidak tepat jika diterapkan dalam masalah yang akan di-qiyâs-kan,

\footnotetext{
${ }^{10}$ Muhammad Khudari Bik, Tarikh al-Tasyri al-Islami (Cet. V; Kairo: Matba'ah al-Istiqamah, 1939 M./1358 H.) hal. 204; Muhammad Abû Zahrah, Us $\underline{u} l$, h. 207.
} 
karena itu secara istihlâan harus dialihkan qiyâs tersebut kepada qiyâs khafi. Sebagai contoh dari bentuk ini dapat dilihat dari kasus wakaf terhadap sebidang tanah. Menurut qiyâs jaliy, wakaf adalah sama dengan jual beli karena sama-sama merupakan pemindahan hak milik. Kalau hanya di-qiyâs-kan dengan qiyâs jaliy, maka yang terjadi hanya pemindahan hak, padahal tujuan wakaf adalah berbeda dengan tujuan jual beli. Dalam wakaf tujuan dari pengalihan hak adalah untuk memperoleh manfaat. Karena itu tanah yang diwakafkan bila berupa sawah perlu digarap dan diairi. Kalau hanya di-qiyâs-kan pada jual beli penggarapan dan pengairan tidak termasuk di dalamnya, karena itu untuk bermanfaatnya barang yang diwakafkan dialihkan qiyâs tersebut dari qiyâs jaliy (jual beli) kepada qiyâs khafiy, yaitu transaksi sewa menyewa. Dengan kata lain, baik pada wakaf maupun sewa menyewa transaksi yang dimaksudkan dari keduanya adalah pengambilan manfaat. ${ }^{11}$

Sedangkan bentuk kedua dari istihsân adalah yang mengecualikan hukum juziyyah dari hukum kuliy berdasarkan dalil. Dalam hal ini seperti ketentuan bahwa Allah secara kulliy telah melarang mengadakan jual beli atau perjanjian (akad) terhadap barang yang tidak terdapat di tempat akad. Namun dengan jalan istihssân dengan mengecualikan dengan memakai hukum juziyyah akad yang semacam itu diperbolehkan karena menyangkut kebutuhan manusia yang sesungguhnya didasarkan pada unsur saling kenal di antara mereka. Termasuk di dalam istihssân bentuk kedua ini adalah bahwa para fuqahâ telah menetapkan bahwa orang yang bodoh yang tidak dapat membelanjakan hartanya tidak sah amal baiknya, tetapi berdasarkan istihhsân dikecualikan perbuatan wakaf atas dirinya ketika masih hidup. Jalan istiḩsân ini dengan wakaf atas dirinya itu berarti mempercayakan tanahnya agar tidak disia-siakan. Hal ini telah disepakati dan yang demikian itulah yang dimaksud dengan membelanjakan sesuatu. ${ }^{12}$

\section{Bentuk-Bentuk Istihsan}

\footnotetext{
11 'Abd al-Wahâb Khallâf, 'Ilm Usîul.., h. 80.

12 'Abd al-Wahâb Khallâf, 'IIm Us $\underline{s} \hat{u} l . .$, h. 81-82.
} 
Sebagaimana uraian yang lalu, bahwa istihsan menurut pandangan ulama Hanafiyyah memiliki sandaran yang jelas, sehingga tidak dapat dikatakan sebagai dalil hukum yang sandarannya adalah hawa dan nafsu. Mujtahid di dalam menggunakan dalil istihsan senantiasa memperhatikan rambu-rambu kepatutan yang disandarkan pada dalil hukum yang telah disepakati. Hal itu dapat dilihat dari bentuk-bentuk dalil istihsan berikut ini :

1. Al-Istihsân bi al-Nas (الإستحسان بالنص), atau istihsân yang sandarannya adalah nas, yaitu beralihnya seorang mujtahid dari ketentuan hukum qiyâs karena jika tetap diterapkan qias tersebut, maka akan bertentangan dengan hukum nas, misalnya tentang jual beli salam. ${ }^{13}$ Jual beli salam atau pesanan dalam ketentuan umum yang bersandarkan qiyâs tidak dibolehkan karena merupakan transaksi jual beli yang barangnya belum ada. Namun ketentuan tersebut tidak dapat dipakai karen a ada nas lain, yaitu berupa hadis Nabi yang menyebutkan kalau Nabi melarang jual beli terhadap sesuatu barang yang tidak ada di tempat kecuali pada jual beli salam (pesanan).

2. Al-Istihsân bi al-Qiyâs al-Khafiy' (الإستحسان بالقياس الخفى) yaitu atau istihsân yang sandarannya adalah qiyâs khafiy atau qiyâs yang tersembunyi, yaitu beralihnya seorang meninggalkan qiyâs yang telah nyata (qiyâs jaliy) kepada qiyâs yang tersembunyi (qiyâs khafiy). Contoh yang masyhur adalah tentang air yang dijilat oleh burung buas, seperti elang dan gagak. Secara qiyâs jaliy air yang bekas dijilat oleh burung buas tidak bersih, karena termasuk dalam binatang buas dan dagingnya haram dimakan. Namun secara istihsân dengan beralih kepada qiyâs khafiy dalam hal ini burung buas tidak di qiyâs kan kepada binatang buas, tetapi di qiyâs kan kepada burung biasa yang bekas jilatannya dipandang bersih tidak najis, karena tidak bersentuhnya liur

${ }^{13}$ Kata salam disebut dengan arti al-taqdim (mendahulukan) dan al-taslim (menyerahkan), sedangkan secara istilah kata salam ini diartikan dengan suatu akad (transaksi) jual beli dengan mendahulukan pembayaran terhadap harga barang sementara barang yang dipesan datan kemudian. Lebih lanjut lihat Muhammad al-Jurjaniy, Kitab Ta'rifat (Singapore: al-Haramain, t.t.), h. 120. 
burung dengan air karena burung menggunakan paruh bukan langsung dengan lidahnya.

3. Al-Istihsân bi al-'Urf (الإستحسان بالعرف), yaitu istihsân yang sandarannya 'urf (adat). Dalam hal ini mujtahid beralih dengan tidak menggunakan caracara yang umum dipakai, tetapi menggunakan cara lain dengan bersandarkan kepada kebiasaan yang telah umum berlaku. Contohnya seperti menggunakan tempat permandian umum, dalam ketentuan umum melalui transaksi jual beli, maka harga yang harus dibayar oleh orang yang menggunakannya harus disesuaikan dengan jumlah air yang digunakan selama mandi atau melalui akad sewa menyewa dengan melihat waktu yang digunakan. Secara istihsân ketentuan umum tersebut ditinggalkan dan beralih kepada 'urf atau adat kebiasaan yang berlaku dan diterima semua pihak.

4. Al-Istihsân bi al-Darurah, (الإستحسان بالضرورة)yaitu istihsân yang sandarannya adalah darurah. Dalam hal ini mujtahid beralih dari ketentuan umum yang harus diikuti karena adanya keadaan darurat yang mengendaki pengecualian. Contohnya air sumur yang kemasukan najis, menurut ketentuan umum benda yang terkena najis harus dibersihkan sehingga hilanglah najis tersebut. Dalam kasus ini tidak mungkin akan berhasil dengan baik, karena setiap kali air dituangkan ke dalam sumur ia akan bercampur dengan air yang sudah ada di dalamnya. Karena itu dengan istihsân darurat cukup dengan menuangkan beberapa galon saja air ke dalam air yang menurut anggapan sudah dapat dikatakan bersih, maka air itu pun menjadi bersih kembali. Keadaan darurat tadi telah menghendaki agar orang tidak mendapat kesulitan dalam mendapatkan air untuk beribadah dan kebutuhan hidupnya. ${ }^{14}$

${ }^{14}$ Penjelasan saling melengkapi lihat al-Sarkhasiy, Usul, hl. 203-205; al-Syatibiy, alMuwafaqat, hal. 207; Abû Zahrah, Us ûl, hal. 209-210, Husain Hamid Hasan, Nazariyah al-Maslahah fi al-Fiqh al-Islamiy (Kairo: Dar al-Nahdah al-'Arabiyyah, 1971), hal. 242-245; Abd al-Karim Zaidah, al-Wajiz, hal. 233-234; Amir Syarifudin, Ushul Fiqh, h. 310-312. 


\section{Argumentasi Penolakan Istihsan Oleh Al-Syafi'iy}

Ulama yang menolak dalil istihsan dimasukkan dalam dalil hukum Islam umumnya berhujjah bahwa dalil tersebut terlalu lemah sandarannya, karena hanya didasarkan argumen para mujtahid saja. Tidak ada argumentasi nas atau akal yang menjadi sandarannya. Adanya bentuk-bentuk istihsan ssebagaimana diuraikan di atas sebagai argumentasi mereka yang mendukungnya tidak lebih sebenarnya jalur qiyas, karena itu istihsan tidak dapat dikatakan sebagai dalil yang berdiri sendiri. Dalil yang tidak dapat berdiri sendiri maka tidaklah dapat dikatakan sebagai dalil hukum.

Dari keseluruhan ulama yang menolak dalil hukum istihsan, al-Syafi'iy adalah ulama yang keras menyatakan Al-Syâfi'iy telah membatalkan dalil dan penggunaan istihsân di dalam ijtihad. Al-Syâfi'iy menyebutkan beberapa alasan ditolaknya suatu dalil istihsân sebagai metode istinbât hukum, antara lain:

1. Istihsân tidak termasuk di dalam dua macam syari'at, yaitu bukan yang memiliki nas yang jelas dan bukan pula berasal dari kandungan nas seperti qiyâs. Jika memang istihsân masuk dalam salah satu ketentuan itu maka, boleh dipakai, tetapi jika berada di luar dua ketentuan itu maka berarti telah menganggap Allah SWT meninggalkan beberapa persoalan kepada manusia tanpa ada ketentuan hukumnya. ${ }^{15}$ Hal ini sangat bertentangan dengan firman Allah:

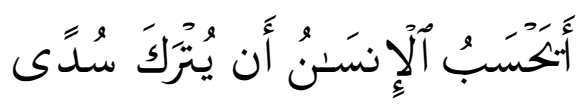

"Apakah manusia mengira, bahwa ia akan dibiarkan begitu saja” QS. AlQiyamah (75):36

2. Banyak ayat-ayat Al-Qur'an yang memerintahkan agar taat kepada Allah dan Rasul-Nya dan melarang manusia, mengikuti hawa nafsu. ${ }^{16}$ Allah juga

15 al-Syâfi'iy,al-Umm, juz VII. h. 271.

${ }^{16}$ al-Syâfi'iy, al-Umm, Juz VII h. 267. di dalam kitab al-Umm itu istihsân dianggap oleh alSyâfi'iy sebagai pengambilan hukum yang mengikuti hawa nafsu yang sangat bertentangan dengan AlQur'an dan hadis berdasarkan firman Allah:

$$
\text { وان احكم بييتهم بما انزل الله ولا تتبع اهو اءهم }
$$


memerintahkan kepada manusia ketika terjadi pertentangan agar kembali kepada kitabullah, firman Allah:

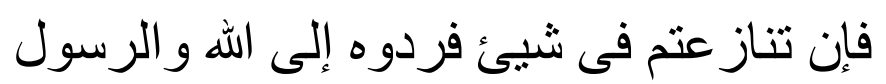

"Kemudian jika kamu berlainan pendapat tentang sesuatu, maka kembalikanlah ia kepada Allah dan Rasul"'

Istihsân tidak termasuk di dalam bagian kitab atau sunnah dan tidak pula merujuk kepada kitab dan sunnah, akan tetapi berada di luar itu. Oleh karena itu istihlân tidak bisa diterima sebagai sumber hukum kecuali jika didukung dengan adanya dalil dari Al-Qur'an dan sunnah yang menunjukkan dapat diterimanya dalil ini. Sedang ini tidak terdapat satu dalil pun yang menunjukkan hal itu.

3. Nabi Muhammad sendiri tidak pernah memberi fatwa berdasarkan istihs juga tidak pernah berpendapat berdasarkan hawa nafsunya. Rasulullah tidak mewajibkan sesuatu apapun kecuali pasti berdasarkan wahyu, baik yang diterima berupa bacaan Al-Qur'an maupun yang bukan merupakan bacaan Al-Qur'an. ${ }^{17}$ Sebagai contoh ketika beliau ditanya tentang seorang laki-laki yang berkata kepada istrinya "Kamu bagiku mirip punggung ibuku" beliau tidak memberikan fatwa berdasarkan istiḩsân melainkan beliau menunggu sampai turun ayat zihar beserta kafarah-nya. Demikian pula beliau menunggu wahyu terhadap kasus li'an atas pertanyaan seorang laki-laki yang mendapati istrinya bersama laki-laki lain dan menuduhnya berbuat zina.

Jika ada seseorang yang memberi fatwa dengan kedalaman perasaan fiqihnya atau dengan istihsân, maka pasti yang pertama melakukannya adalah Nabi Muhammad saw, tetapi pada kenyataannya beliau tidak menggunakan istihsân. Beliau tetap menunggu turunnya wahyu atau bila tidak turun wahyu beliau memutuskannya berdasarkan bimbingan dari Allah SWT.

\footnotetext{
"Dan hendaklah kamu memutuskan perkara di antara kamu dengan apa yang diturunkan Allah kepadamu dan janganlah kamu mengikuti hawa nafsumu” QS. Al-Maidah (5):49.

${ }^{17}$ al-Syâfi'iy, al-Umm, Juz VII, h. 268.
} 
4. Nabi Muhammad saw juga tidak berkenan terhadap para sahabat yang pergi ke daerah lain dan memberi fatwa dengan cara istihsân. ${ }^{18}$ Karena itu beliau mencela perbuatan sebagian sahabat yang membakar seorang musyrik yang berlindung di bawah sebuah pohon. Begitu juga beliau memandang perbuatan yang bodoh dan tercela perbuatan Usamah yang membunuh seorang laki-laki yang mengucapkan kalimat la ilaha illa Allah karena ucapan itu diucapkan di bawah ancaman pedang. Sekiranya perbuatan sahabat Usamah itu direstui Nabi tentu beliau tidak akan mencelanya.

5. Istihsân dipandang oleh al-Syâfi'iy sebagai ketentuan yang tidak memiliki batasan yang jelas dan tidak pula mempunyai kriteria-kriteria yang bisa dijadikan standar untuk membedakan antara yang hak dan yang batil seperti qiyâs. Jika seandainya setiap hakim, mufti atau mujtahid diperkenankan menggunakan dalil istiḩsân dengan tanpa adanya batasan, niscaya persoalannya akan bias. Dan dalam suatu masalah baru yang muncul akan mendapat jawaban hukum yang beragam sesuai dengan kecenderungan dan kemampuan masing-masing mufti dalam menangkap dan menerapkan dalil istihsân. ${ }^{19}$

Oleh karena itu bukan tidak mungkin dalam satu masalah terdapat bermacam-

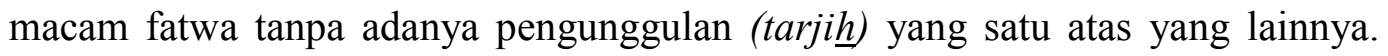
Sebab tidak ada ukuran dan batasan yang bisa dipakai untuk melakukan tarji $\underline{h}$ selama asasnya adalah istiḩsân.

6. Seandainya istihsân boleh dipakai oleh seorang mujtahid, sementara ia tidak berpegang kepada nas atau mengacu kepada nas dan hanya berpegang kepada kemampuan akalnya semata, maka niscaya istih $\underline{\text { sân }}$ boleh dilakukan oleh orang yang tidak mempunyai pengetahuan tenang Al-Qur'an dan sunnah. ${ }^{20}$ Bahkan $^{2}$ tidak jarang di antara orang-orang seperti itu ada yang memiliki akal melebihi

\footnotetext{
18 al-Syâfi'iy, al-Umm, Juz VII , h. 276.

19 al-Syâfi'iy, al-Umm, Juz VII, h. 273.

20 al-Syâfi'iy, al-Umm, Juz VII, hal. 274; al-Syâfi'iy, al-Risâlah.., h. 505.
} 
akal yang dimiliki oleh ulama yang memahami Al-Qur'an dan sunnah. Mengapa yang satu boleh melakukan istihsân sementara yang lainnya tidak dibolehkan.

Beberapa alasan di atas menurut oleh al-Syâfi'iy merupakan dasarnya menolak istiḩân termasuk dalam wilayah istinbât hukum. Istihsân hanya berdasarkan hawa nafsu yang seenaknya yang tidak berpijak kepada ketentuan nas atau memiliki sandaran qiyâs yang jelas. Istiḩsân hanya bersandar kepada penggunaan akal yang semena-mena. Karena itu al-Syâfi'iy berkesimpulan dengan menganggap orang yang menggunakan istihhsân sesungguhnya telah membuat-buat hukum syari'at sendiri. ${ }^{21}$ Hal itu semua menunjukkan bahwa hukum yang dihasilkan oleh seorang mujtahid yang berdasar ketentuan istihsân adalah didasarkan pada keinginan mencari kesenangan dan selera pribadi semata-mata:

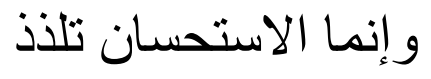

selera"22 "Sesungguhnya istihsân adalah ketentuan hukum yang didasarkan pada

Al-Syâfi'iy memberikan ilustrasi bahwa orang yang menggunakan istiḩsân bagaikan orang yang menjalankan shalat menghadap ke suatu arah yang menurut istihsân-nya adalah arah ka'bah. Padahal dirinya sendiri tidak pernah mengiringi keyakinannya itu dengan petunjuk atau dalil-dalil yang telah ditentukan syarak di dalam menentukan arah. Perbuatan seperti itu yang hanya berdasar istiḩsân menurut al-Syâfi'iy sama saja dengan rasa nyaman dan selera seseorang. Jika diperkenankan menggunakan istiḩsân mengenai soal agama, maka kebolehan itu pasti diperuntukkan bagi orang yang mempunyai akal secara umum dan tidak dibatasi pada ahli ilmu yang dapat membuat istihhsân. Kalau istiḩsân ini diperkenankan tentunya akan dibolehkan

${ }^{21}$ Perkataan al-Syâfi'iy yang sering dikutip oleh para ulama ushul dalam usaha menjelaskan sikap al-Syâfi'iy adalah (من استحسن فقد شرع - "Siapapun yang menggunakan istihsânberarti telah membuat syari'at sendiri”"Lebih lanjut lihat, Muhammad Khudari Bik, Usûl al-Fiqh (Cet. VI; Mesir al-Maktabah al-Tijariyah, 1969 M./1389 H.), hal. 334; 'Abd al-Wahâb Khallâf, 'Ilm Us sûl.., h. 83.

${ }^{22}$ al-Syâfi'iy, al-Risâlah, h. 507. 
siapa saja membuat syari'at dalam setiap masalah sesuai dengan selera, dari masingmasing; setiap individu akan membuat hukum syarak sesuai untuk keperluan dirinya sendiri. $^{23}$

Secara ringkas dapat dikatakan bahwa al-Syafi'iy memandang istihsân sebagai perbuatan dalam menetapkan hukum tanpa dalil yang nyata, tanpa nas atau ijmak, dan tidak berdasarkan qiyâs. Dengan kata lain, istihsân dianggapnya ketentuan yang lepas sama sekali dari ketentuan syariat, sehingga sama dengan menetapkan hukum berdasarkan selera mujtahid. Ketentuan syariat hanya boleh terbit dari pembuat syariat saja (syãri'), yaitu Allah. Mujtahid yang menggunakan istihsân dipandang mensejajarkan dirinya dengan Allah, yaitu sama-sama membuat syariat. Jika yang dimaksud dengan dalil istihsân itu adalah seperti yang digambarkan oleh al-Syafi'iy tersebut, maka sudah pada tempatnya al-Syafi'iy menolak kehujjahan istihsân tersebut.

Namun menurut kebanyakan ulama alasan-alasan yang dipakai al-Syâfi'iy dalam menolak istihsân di atas tidak memiliki korelasi atau hubungan dengan istihlân yang diperkenalkan oleh madzhab Hanafi. Sebab ada beberapa istihsân yang ditolak al-Syâfi'iy sesungguhnya dapat ditolerir dan diakui dalam metode istinbât hukum al-Syâfi'iy. Bahkan dalam prakteknya, al-Syafi'iy ada menggunakan istihsân . Misalnya pada kasus mut'ah (pemberian suami ${ }^{24}$ bagi isteri yang ditinggalkan alSyafi'iy menggunakan istihsân. Dalam hal ini ia mengatakan :

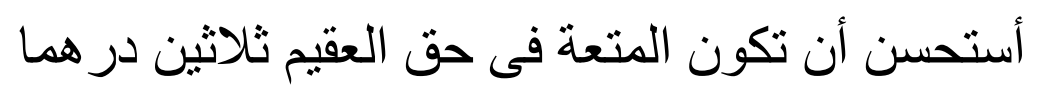

${ }^{23}$ al-Syâfi'iy, al-Umm, Juz VII, hal. 272; 'Abd al-Wahâb Khallâf, 'Ilm Us $\underline{u}$ l..,, hal. 83.

${ }^{24}$ Mut'ah, pemberian suami kepada isteri yang dicerai berupa 30 dirham menurut al-Syafi'iy sebagai suatu standar yang mustahab (dianjurkan) untuk mut'ah. Namun di tempat lain al-Syafi'iy memberikan alternatif bahwa dengan menyebutkan bahwa pemberian itu dapat berupa seorang budak pelanyan (khadam) atau miqna'ah (penutup kepala) atau 30 dirham. Menurut ashab al-Syafi'iy (pengikut al-Syafi'iy) 30 dirham adalah batas minimal jumlah mut'ah, batas maksimal adalah berdasarkan kesepakatan kedua belah pihak. Lihat al-Nawawiy, Raudhat al-Talibih wa 'Umdat alMuftn, Juz VII (Beirut: al-Maktab al-Islamiy, 1991), h. 322; al-Nawawiy, Minhaj al-Talibin wa 'Umdat al-Muftin, Juz II (Singapura; al-Haramain, tt.), h. 92. 
Saya memandang baik untuk menetapkan mut'ah pemberian suami bagi isteri yang dicerai dan tidak punya anak sebesar tiga puluh dirham. ${ }^{25}$

Termasuk juga pernyataan al-Syafi'iy yang membolehkan mengambil sumpah dengan Al-Qur'an dengan menggunakan istihsân . Pendapatnya itu dikeluarkan karena melihat Mutarrif ibn Mazin di Sana' melakukan pengambilan sumpah dengan Al-Qur'an. ${ }^{26}$ Al-Syafi'iy menilai perbuatan Mutarib itu sebagai perbuatan yang baik, ia mengatakan :

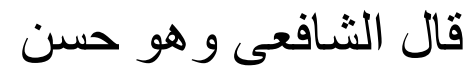

Al-Syafi'iy berkata : itu adalah perbuatan yang baik. ${ }^{27}$

Uraian al-Syafi'iy di atas merupakan bukti bahwa dalam prakteknya ia senantiasa menggunakan istihsân. Dan banyak pula para ulama menguraikan bahwa al-Syafi'iy pada dasarnya tetap menggunakan istihsân sebagai dalil hukum sebagaimana dicontohkan di atas. Pertanyaannya, sesungguhnya istihsân mana yang ditolaknya sebagai dalil hukum. Menurut Amir Syarifuddin, al-Syafi'iy tidak menolak istihsân secara keseluruhan, istihsân yang ditolaknya adalah istihsân dalam arti beralihnya seorang mujtahid dari qiyâs jaliy kepada qiyâs khafiy (istihsân al-qiyâs) dan istihsân yang bersandarkan adat kebiasaan (istihsân al-'urf). Penolakan al-Syafi'iy dalam dua istihsân itu adalah karena ada unsur talazzuz atau seenaknya. Seandainya boleh meninggalkan qiyâs tentu orang yang tidak mempunyai ilmu pun akan dengan mudahnya menggunakan istihsân sewaktu ia tidak menemukan keterangan hukum. ${ }^{28}$

Nahrawi masih melihat adanya satu macam istihsân yang benar-benar diperselisihkan, yaitu menetapkan hukum berdasarkan ruh tasyri', yaitu prinsip keadilan atau kaidah umum lainnya yang menyimpang dari qiyâs karena suatu alasan.

\footnotetext{
${ }^{25}$ Abu Zahrah, Usul, 268.

26 قال الثافعى ور أيت مطرفا بصنحاء يحلف على المصحف al-Syafi'iy, al-Umm, Juz VII, h. 36.

${ }^{27}$ Abu Ishaq al-Syiraziy, al-Muhazzab fi Fiqh al-Imam al-Syafi'iy, Juz II, h. 322.

${ }^{28}$ Amir Syarifuddin, Usul, h. 314.
} 
Hal ini sangat berbahaya, dan merupakan yang sangat ditentang oleh al-Syafi'iy tetapi digunakan oleh ulama lainnya. Sebagian ulama yang menggunakan istihsân seperti ini menganggap ia sejalan dengan tuntutan ruh syariat, prinsip keadilan dan qiyâs, serta menghindari kerusakan (mafsadah), menciptakan maslahat, mendapatkan kemudahan dan mengelakkan kesulitan. Istihsân seperti ini untuk mendapatkan yang lebih baik dan bermanfaat bagi manusia. ${ }^{29}$

Imam al-Ghazâliy ketika membahas persoalan istihsân ini menyatakan bahwa adanya peralihan suatu qiyâs kepada dalil lain yang lebih kuat, disepakati oleh seluruh ulama ushul, namun beralihnya mujtahid itu tidaklah dinamakan dengan istihsân . Karena itu, secara konsep al-Ghazâliy dapat menerima istihsân yang bermakna peralihan kepada dalil yang lebih kuat, seperti Al-Qur'an, sunnah atau ijmak, namun menamakan hal itu dengan istihsân tidak dapat diterimanya, karena istilah itu cenderung untuk dipakai dalam arti membuat-buat syariat sendiri. ${ }^{30}$

\section{E. Kesimpulan}

Adanya perbedaan dalam kehujjahan istiḩsân di kalangan ulama pada hakekatnya didasarkan kepada tidak sepakatnya pihak yang berselisih tentang cakupan dan pengertian istiḩsân, Ulama yang menggunakan istihsân sebagai hujjah menyampaikan kepada ulama yang tidak menggunakan istiḩsân sebagai hujjah dengan pengertian lain. Jika mereka yang berbeda pendapat itu sepakat mengenai batasan pengertian istihsân, maka sudah pasti mereka tidak akan berbeda pendapat tentang istihsân dapat dijadikan sebagai hujjah dan dalil hukum. Sebab pada dasarnya istihsân itu adalah pindahnya seorang mujahid dari dalil yang jelas atau dari hukum kulliy karena ada dalil yang menuntut perpindahan itu, sehingga tidak dapat dikategorikan pembentukan hukum dengan nafsu. Seorang hakim dalam prakteknya terkadang harus menyalahi cara berpikirnya terhadap beberapa kasus yang

\footnotetext{
${ }^{29}$ Nahrawiy, h. 419.

${ }^{30}$ Abu Hamid al-Ghazâliy, al-Mankhul min Ta'liqat al-Usul (Beirut: Dar al-Fikr, 1980), h. 274-277; al-Ghazâliy, al-Mustasfa, Jilid I, h. 274.
} 
sebenarnya menuntut adanya perpindahan karena zzahir undang-undang tidak jelas mengatur hal itu. Hal ini pun termasuk dalam jenis istihs $s \hat{n} .^{31}$

Namun demikian perlu juga melihat kondisi historis yang menyebabkan mengapa al-Syâfi'iy menolak istihsân dalam istinbât hukum kala itu. Informasi yang ditemukan, antara lain, karena baik Abu Hanifah dan Malik serta sahabat-sahabat beliau tidak pernah menerangkan secara rinci dan detail dimaksudkan dan dikehendaki dengan istihsân itu sehingga dapat menyebabkan pemakaian istiḩsân itu berpaling dari makna aslinya. ${ }^{32}$ Karena itu serangan yang paling tajam yang dilancarkan adalah ketika al-Syâfi'iy mendengar kalimat istiḩsân dipakai oleh pengikut-pengikut Abu Hanifah yang berdiskusi dengan beliau tanpa menerangkan apa yang mereka maksudkan dengan kalimat itu. ${ }^{33}$ Boleh jadi para lawan diskusi alSyâfi'iy mempergunakan kalimat istihsân di waktu mereka terpojok dan tidak dapat lagi mengemukakan suatu dalil akibat sikap bertaklid kepada imam-imam mereka. Tatkala al-Syâfi'iy menanyakan apa yang dimaksud dengan hakikat istiḩsân, mereka pun tidak dapat menjawabnya secara tegas dan pasti. ${ }^{34}$

\footnotetext{
31 'Abd al-Wahâb Khallâf, 'Ilm Us $\underline{s}$ ul..,, h.83.

${ }^{32}$ Definisi dan batasan yang disebutkan tentang istihsân barulah secara elas diterangkan pada masa membuat dalil bagi dasar yang dipergunakan yang terjadi sesudah masa al-Syâfi'iy, barulah tokoh-tokoh fikih dalam madzhab Hanafi membuat definisinya yang menerangkan hakekat, yang mereka ungkapkan dari cabang-cabang hukum yang dinukilkan dari para Imam mereka. Lebih jelas lihat T.M. Hasbi Ash Shiddieqiy, Falsafah Hukum Islam (Jakarta: Bulan Bintang, t.t. ), h. 305-306.

${ }^{33}$ Menurut Khudariy Bik, tampaknya al-Syâfi'iy menunjukkan bantahannya atas istihsân itu kepada Muhammad ibn al-Hasan yang selalu mengatakan "Saya ber-istihsân dan meninggalkan qiyâs, Abû Hanifah ber-istihsân dan meninggalkan qiyâs" dan menganggap mereka melakukan istihsân dengan pengertian seperti yang dimaksudkannya itu. Akan tetapi bagi para pengikut Muhammad ibn Hasan sendiri, istihsân yang dimaksudkannya itu adalah meninggalkan qiyâs kepada as al tertentu dan beralih kepada suatu atsar (hadis) atau kepada suatu prinsip umum, seperti ra'y yang dikenal oleh ulama mutaqaddimin, atau beralih kepada qiyâs lain dengan menggunakan asal lainnya. Lebih jelas lihat Khudariy Bik, Tarikh, h. 205.

${ }^{34}$ Ash Shiddieqiy, Falsafah Hukum Islam, h. 305-306
} 


\section{Daftar Pustaka}

Abu Hamid al-Ghazâliy, al-Mankhul min Ta'liqat al-Usul (Beirut: Dar al-Fikr, 1980). Abu Ishaq al-Syiraziy, al-Muhazzab fi Fiqh al-Imam al-Syafi'iy, Juz II.

Abû Ishaq Ibrahim ibn Musa al-Syâtibi, al-Muwafaqat fi Usîl al-Syarî'ah, Juz IV (Mesir: al-Maktabah al-Tujariyyah al-Kubra, t.t.) hal. 3-7; Fazlurrahman, Islam (Chicago: university of Chicago Press, 1979).

al-Nawawiy, Minhaj al-Talibin wa 'Umdat al-Muftin, Juz II (Singapura; al-Haramain, tt.).

al-Nawawiy, Raudhat al-Talibih wa 'Umdat al-Muftn, Juz VII (Beirut: al-Maktab alIslamiy, 1991).

Al-Sarkhasiy, Usul al-Sarakhasiy, jilid II (Beirut: Dar al-Kutub al-'Ilmiyyah, 1993) hal. 200; al-Amidiy, al-Ihkam, Jilid III.

Lihat Muhammad Abû Zahrah, Ushûl al-Fiqh (T.tp.: Dâr al-Fikr al-'Arabîy, t. t).

Muhammad Adîb Sâlih, Lamhat fi Usî̀l al-hadîts (Beirut: al-Maktab al-Islâmiy, 1399 H.); Muhammad ibn Ismaîl al-Sanânî, Taudîh $\underline{h}$ al-Afkâr li Ma'âni Tanqîh alAnżâr, Juz I (Kairo: Maktabah Khânijiy, 1966 M.).

Muhammad al-Jurjaniy, Kitab Ta'rifat (Singapore: al-Haramain, t.t.).

Muhammad Khudari Bik, Tarikh al-Tasyri al-Islami (Cet. V; Kairo: Matba'ah alIstiqamah, 1939 M./1358 H.).

Muhammad Khudari Bik, Usîul al-Fiqh (Cet. VI; Mesir al-Maktabah al-Tijariyah, 1969 M./1389 H.).

Muhammad Mûsa Tiwâna, al-Ijtihâd (T.tp.: Dâr al-Kutub al-Hadîtsah, t.t. ).

Mustafâ al-Sibâiy, al-Sunnah wa Makânatuhâ fì al-Tasyrî' al-Islâmiy (t.tp.: Dâr alQaumiyyah, 1966).

Syed Mahmudunnasir, Islamic Concept and History (New Delhi: Nusrat Ali Nasri for Kitab Bhavan, 1981).

T.M. Hasbi Ash Shiddieqiy, Falsafah Hukum Islam (Jakarta: Bulan Bintang, t.t. ). 